\title{
Sydowia polyspora is both a Foliar Endophyte and a Preemergent Seed Pathogen in Pinus ponderosa
}

\author{
Mary Ridout ${ }^{\dagger}$ and George Newcombe, Department of Forest, Rangelands and Fire Sciences, University of Idaho, Moscow 83844-1133
}

\begin{abstract}
Poor seedling performance and reduced seed emergence are often ascribed to known pathogens that cause low seedling recruitment and poor seed emergence in forest nurseries and regeneration plantings. On the other hand, foliar endophytes are often overlooked as a source of poor emergence or tree seedling disease. Here, we show that an endophytic fungus common to the foliar microbiome of Pinus ponderosa acts as a cryptic pathogen in delaying emergence. In a series of experiments, we

inoculated seed of $P$. ponderosa with a suspension of Sydowia polyspora $12 \mathrm{~h}$ prior to sowing. $S$. polyspora reduced seed emergence of its host, $P$. ponderosa, by as much as $30 \%$. A tetrazolium chloride viability assay showed that $S$. polyspora reduces emergence by preventing germination; seed remained viable. In sum, pathogens affecting tree seed emergence and seedling recruitment may be endophytic as well as in seed and soil and deserve greater attention in studies of natural regeneration.
\end{abstract}

Seedling recruitment is critical to natural regeneration in plant communities and, likewise, consistent seedling emergence is critical in forestry nurseries in order to produce sufficient quantities of stock for reforestation. Most plant regenerative losses in wildland communities are thought to be due primarily to seedling mortality from herbivory, drought, and microbial attack (Moles and Westoby 2004). Mortality from microbial attack in both nurseries and natural regeneration is typically attributed to the well-studied seed- and soilborne genera Fusarium, Cylindrocarpon, Rhizoctonia, Pythium, and Phytophthora, which are most commonly identified as seedling pathogens (Augspurger and Wilkinson 2007; Gallery et al. 2007; Hersh et al. 2012; Huang and Kuhlman 1990; Packer and Clay 2000; Salerno and Lori 2007). Pathogens have been strongly implicated in the dynamics of recruitment and regeneration of plant communities (Borer et al. 2007; Connolly and Orrock 2015; Crist and Friese 1993; Dalling et al. 2011; Eriksson and Ehrlén 2008; Meyer et al. 2008), making the study of them important to the field of restoration ecology.

Conifers within the interior pine forests of the Pacific Northwest contain a diverse community of endophytic microbes throughout their tissues (Ganley et al. 2004; Hoff et al. 2004; Ganley and Newcombe 2006; Ridout and Newcombe 2015). Although some pathogenic fungi are known to asymptomatically colonize vegetative tissues (Ganley and Newcombe 2006; Ridout and Newcombe 2015) and seed endophytes are known to have marked effects on germination and seedling vigor (Clay 1987; Puente et al. 2009; Raghavendra et al. 2013), foliar endophytes are not thought to contribute to seedling mortality.

One of the more common needle endophytes of Pinus ponderosa Lawson \& C. Lawson var. ponderosa C. Lawson is Sydowia polyspora (Bref. \& Tavel) E. Müll. Under certain conditions, this fungus will function as a minor, weak foliar pathogen causing small foliar lesions (Funk 1985) It is also associated with shoot and tip dieback and injury-related blue stain in several Pinaceae species (Smerlis 1970). The fungus can be opportunistically pathogenic in foliage

${ }^{\dagger}$ Corresponding author: M. Ridout; E-mail: mridout@uidaho.edu

Funding: Funding for this project was provided through the National Science Foundation Center for Advanced Forest Systems award number 11P0968821.

Accepted for publication 21 October 2017.

This article is in the public domain and not copyrightable. It may be freely reprinted with customary crediting of the source. The American Phytopathological Society, 2018. of Pinus spp., Abies spp., and Pseudotsuga menziesii (Mirb.) Franco in the northern hemisphere (Carroll and Carroll 1978; Funk 1985; Smerlis 1970; Talgø et al. 2010) but it is also frequently isolated as an endophyte from asymptomatic foliage of these same conifers (Carroll and Carroll 1978; Ganley et al. 2004; Ridout and Newcombe 2015; Smerlis 1970). It is also found as a saprophyte in litter layers (Boberg et al. 2011; Koukol 2009).

During a greenhouse experiment to examine potential effects of common Pinus ponderosa endophyte isolates on seedling health (unpublished data), we observed reduced emergence of seedlings in some treatments. Emergence appeared to be strongly reduced by $S$. polyspora. To confirm this finding, we conducted further experiments.

We hypothesized that $S$. polyspora reduced emergence by either killing seed or simply delaying their germination. To test this hypothesis, we inoculated seed with the endophyte prior to sowing and determined effects on emergence of two provenances of $P$. ponderosa. We also tested the putative seed pathogen on seed of another host, Pseudotsuga menziesii (Mirb.) Franco var. glauca (Beissn.) Franco. Finally, we examined the effects of the needle endophyte on seed viability.

\section{Materials and Methods}

Isolation of $\boldsymbol{S}$. polyspora. The foliar microbial communities of 10 healthy Pinus ponderosa trees in the University of Idaho Experimental Forest, Latah County, ID were sampled in August 2010 to obtain isolates for study. To identify common foliar microbes, 100 needles were sampled from the lower crown of 10 trees of $P$. ponderosa, for a total of 1,000 needles. Needles were surface sterilized for $1 \mathrm{~min}$ in $95 \%$ ethanol, $5 \mathrm{~min}$ in $6 \%$ sodium hypochlorite $(\mathrm{NaOCl})$, and $30 \mathrm{~s}$ in $95 \%$ ethanol, according to Ganley and Newcombe (2006), then cut into three sections before plating onto the general fungal medium 4\% (wt/vol) potato dextrose agar (PDA; Difco Laboratories, Inc.).

Tissues were stored at $4{ }^{\circ} \mathrm{C}$ and processed within $72 \mathrm{~h}$ following collection. Following recovery from the plant tissue, fungal isolates were cultured and stored at $4{ }^{\circ} \mathrm{C}$ on PDA. Isolates of interest were identified by micromorphology and, where needed, identities were confirmed with Sanger sequencing (Sanger et al. 1977).

Experiment I: Effects of $S$. polyspora on seed germination of host provenance. To determine potential effects of a common needle endophyte of $P$. ponderosa, $S$. polyspora, on germination and emergence of seed of its host, we treated seed of $P$. ponderos $a$ with the fungus and sowed them in a replicated greenhouse experiment. Seed were sourced from a 2010 seed lot from the provenance of the host tree from which the fungus was isolated, the Flat Creek Unit of the University of Idaho Experimental Forest outside Moscow, ID, and stored at $5{ }^{\circ} \mathrm{C}$ until needed. Four weeks prior to beginning the 
experiment, seed were removed from storage, surface sterilized in $2.5 \% \mathrm{NaOCl}$ for $8 \mathrm{~min}$, and soaked in running water at $22^{\circ} \mathrm{C}$. After $24 \mathrm{~h}$ in the running water, seed were thoroughly rinsed, wrapped in a clean paper towel, sealed in a resealable plastic bag, and placed in stratification at $2{ }^{\circ} \mathrm{C}$. After 4 weeks, seed were removed from stratification and thoroughly rinsed prior to inoculation.

For the experiment, fresh inoculum of $S$. polyspora was grown for 4 weeks on $4 \%$ PDA. Inoculum was made into a suspension by flooding 3-week-old culture plates with sterile distilled water (SDW) and passing a sterile bent glass rod over the culture surface to loosen spores. This suspension was brought to a volume of $50 \mathrm{ml}$ of SDW per plate for a final spore concentration of approximately $6.75 \times$ $10^{6}$ conidia/ml, as determined by brightline hemacytometer counts.

Seeds of $P$. ponderosa were imbibed overnight for approximately $12 \mathrm{~h}$ in the $S$. polyspora inoculum at $22^{\circ} \mathrm{C}$. Seeds of the control treatment were imbibed in SDW. In total, 600 seeds were sown for each treatment (S. polyspora or SDW) in number 1 Sunshine Mix (Sun Gro Horticulture Canada Ltd.) in three 200-count seedling cells per treatment. Trays were arranged in a complete randomized design. Seeds were germinated in the greenhouse at a 16-h daylength and diurnal temperatures of 25 and $16^{\circ} \mathrm{C}$. After 4 weeks, emergence was recorded as presence or absence ( 1 or 0 , respectively) of a seedling per cell. Emergent plants were examined daily during the 4-week period for postemergent disease symptoms.

Experiment II: Effects of $S$. polyspora on seed germination of a second provenance of $P$. ponderosa and on Pseudotsuga menziesii. To confirm results from our first experiment and determine whether the Idaho provenance might be unusually susceptible, we conducted a second experiment. We tested the effects of S. polyspora on germination of both the host provenance from Idaho and a second provenance of Pinus ponderosa from the southern Rocky Mountains, San Isabel National Forest, CO. Because there were insufficient seeds remaining from the 2010 seed lot of the experiment I Idaho provenance, seed from the same Idaho provenance were sourced from a 2012 seeds lot. We also tested the effects of $S$. polyspora on germination of a local provenance of Pseudotsuga menziesii var. glauca to determine whether the fungus would be pathogenic to the seed of this co-occurring host. For each species or provenance, seeds were treated with $S$. polyspora or SDW, as previously described. In all, 600 seed each of endophyte-inoculated or control seeds were sown and germinated in the greenhouse as in experiment I. After 4 weeks, emergence was recorded with emergent plants examined daily during the 4-week period for postemergent disease symptoms.

Experiment III: Posttreatment seed mortality. A final emergence assay was conducted with seed of the Idaho provenance (seed lot 2012) of Pinus ponderosa to determine whether seed mortality was the potential mechanism of $S$. polyspora suppression of emergence. Seeds were treated as previously described, sown in 200-cell trays, and germinated for 4 weeks under previously described greenhouse conditions. Because we were only attempting to determine the condition of the seed and the number of remaining seeds were limiting, we sowed only one 200-cell tray per treatment. Following collection of postemergence data, ungerminated or nonemergent seeds were extracted for viability testing and washed with nonsterile distilled water. Fifty nonstratified, uninouculated seeds were washed with nonsterile distilled water to be tested as a positive control. Fifty more nonstratified, uninouculated seeds were boiled in deionized water for $20 \mathrm{~min}$, then frozen overnight at $-20^{\circ} \mathrm{C}$ to destroy viability to be used as a negative control. All seeds were soaked in SDW for approximately $2 \mathrm{~h}$ prior to the viability assay to soften the seed coat. Seeds were then split longitudinally in half, and the seed halves were submerged in 2,3,5-triphenyl-tetrazolium chloride (TTC) for $20 \mathrm{~h}$, following the protocol by Grano (1958). Ungerminated seeds testing positive for dehydrogenase activity in the embryo (conversion of white TTC to the red 1,3,5-triphenylformazan) were considered viable.

Statistics. All data were categorical (germinated or not) and expressed as frequency counts in two-by-two contingency tables. All emergence data were analyzed using a Pearson's $\chi^{2}$ test of association (Knapp and Anderson 1980; McDonald 2014). Comparisons of viable to nonviable seed in experiment III were also analyzed by Pearson's $\chi^{2}$ test of association.

\section{Results}

Common members of $\boldsymbol{P}$. ponderosa needles. Of the microbes recovered from needles of trees of $P$. ponderosa in a mixed-conifer forest northern Idaho, $S$. polyspora was among the most common (unpublished data). This fungus was recovered from all 10 trees sampled and was only slightly less common than the expected Lophodermium spp. complex (Ganley et al. 2004) and the Elytroderma spp. complex (Ridout and Newcombe 2015), with all three genera composing over $90 \%$ of isolates obtainable on PDA. The isolate we used in our study was identified via morphology and confirmed as S. polyspora by Sanger sequencing (Sanger et al. 1977). Comparisons of the sequence in GenBank with accessions of this taxon revealed $100 \%$ identity to reference accession number JX188241 (Bourret et al. 2013). Our internal transcribed spacer sequence was submitted to the GenBank database as S. polyspora (Bref. \& Tavel) E. Müll. (anamorph: Hormonema dematioides Lagerb. \& Melin) (Wijayawardene et al. 2014), GenBank accession number KP152486.

Pre- and postemergent pathogenicity of $S$. polyspora. In all three emergence experiments, $S$. polyspora, isolated as an endophyte from asymptomatic $P$. ponderosa needles, reduced emergence of its host $P$. ponderosa (Table 1). In the first experiment, $S$. polyspora reduced emergence of the Idaho provenance of P. ponderosa by $13.4 \%$ (Fig. 1; Table 1). In the second experiment, the seed pathogen not only reduced emergence of the Idaho provenance of $P$. ponderosa by $7.6 \%$ but also reduced emergence of the Colorado provenance by $30 \%$ (Table 1). By contrast, S. polyspora had no effect on emergence of Pseudotsuga menziesii var. glauca.

Excavation of nonemergent seed revealed that these seeds had failed to germinate. Emergent seedlings, on the other hand, developed normally. In fact, not one emerged seedling died in any experiment.

S. polyspora effects on Pinus ponderosa seed viability. Although $S$. polyspora significantly reduced emergence in the Idaho Pinus ponderosa provenance, seed viability (as indicated by dehydrogenase activity on viable seed embryos in the TTC viability test) was not significantly reduced by the fungus compared with the uninoculated seed $\left(\chi^{2}=0.017, P=0.8962\right)$ or the uninoculated, nonstratified positive control $\left(\chi^{2}=0.2986, P=0.5848\right)$, as determined by the Pearson $\chi^{2}$ contingency test of association. Seed viability was effectively destroyed by boiling the negative control, providing a visually effective comparison of seed viability and indicating that, although the foliar fungus reduced emergence, it failed to kill seed outright (Fig. 2). Despite no significant loss in viability, emergence of Sydowia-treated seed used to determine effects on viability was still reduced by $23.6 \%$ $\left(\chi^{2}=24.9, P<0.0001\right)$.

\section{Discussion}

Poor seed emergence can cause researchers to focus on wellknown seed- and soilborne seedling pathogens from well-studied genera. In naturally regenerating plant communities, this approach may be over simplistic. If an endophyte such as $S$. polyspora can reduce germination and emergence of $P$. ponderosa, then that focus ought to be broadened.

S. polyspora was previously known only as a foliar endophyte and weak pathogen (Carroll and Carroll 1978; Funk 1985; Smerlis 1970). Here, it was shown to strongly reduce emergence within the provenance from which it was isolated, and also that of a distant provenance. Although emergence varied even within the Idaho provenance by seed lot or age, as seen by variable emergence of control seed, $S$. polyspora always reduced emergence. Thus, effects are not specific to populations, although seed quality (e.g., age) may influence overall emergence and the severity of $S$. polyspora's pathogen effects. For example, the endophyte actually reduced emergence in the older seed of the Colorado provenance to a greater degree than it did in the Idaho provenance. Similarly, older seed collected 
in 2010 which had less emergence of uninoculated seed compared with 2012 seed from the same provenance (Table 1) were more strongly affected by inoculation with $S$. polyspora than the 2012 seed. Even when experiment III was completed a year following experiment II using the 2012 seed lot, S. polyspora more strongly reduced emergence of the older seed.

$S$. polyspora may be specific in its emergence-delaying activities to $P$. ponderosa. Sarmiento et al. (2017) demonstrated that fungi isolated from seed of a host showed greater affinity to that host than to other species and affected germination of various plant species in specific ways. Although S. polyspora is also an endophyte in Pseudotsuga menziesii var. glauca, our Pinus ponderosa isolate did not reduce emergence in Pseudotsuga menziesii var. glauca. Perhaps an isolate from the latter would do so.

The concept of $S$. polyspora as a preemergent seed pathogen is noteworthy considering that it is typically reported as a needle endophyte (Carroll and Carroll 1978), as a secondary pathogen in damaged tissues (Smerlis 1970), or as a minor foliar pathogen (Funk

Table 1. Three successive experiments showing that Hormonema dematioides is a preemergent pathogen of seed of Pinus ponderosa ${ }^{\mathrm{a}}$

\begin{tabular}{|c|c|c|c|c|c|}
\hline Experiment, species (provenance) & Inoculant & Emergence (\%) & Percentage of control & $\chi^{2}$ & $P$ value \\
\hline \multicolumn{6}{|l|}{1} \\
\hline \multirow[t]{2}{*}{ P. ponderosa (Idaho) } & H. dematioides & 55.8 & 86.6 & 9.402 & 0.002 \\
\hline & Control & 64.5 & & & \\
\hline \multicolumn{6}{|l|}{2} \\
\hline \multirow[t]{2}{*}{ P. ponderosa (Idaho) } & H. dematioides & 89.0 & 92.4 & 23.741 & 0.000 \\
\hline & Control & 96.3 & & & \\
\hline \multirow[t]{2}{*}{ P. ponderosa (Colorado) } & H. dematioides & 28.5 & 70.1 & 19.629 & 0.000 \\
\hline & Control & 40.7 & & & \\
\hline \multirow[t]{2}{*}{ Pseudotsuga menziesii var. glauca (Idaho) } & H. dematioides & 94.7 & 101.4 & 0.724 & 0.395 \\
\hline & Control & 93.3 & & & \\
\hline \multicolumn{6}{|l|}{3} \\
\hline \multirow[t]{2}{*}{ Pinus ponderosa (Idaho) } & H. dematioides & 68.0 & 76.4 & 24.900 & 0.000 \\
\hline & Control & 89.0 & & & \\
\hline
\end{tabular}

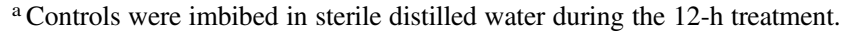

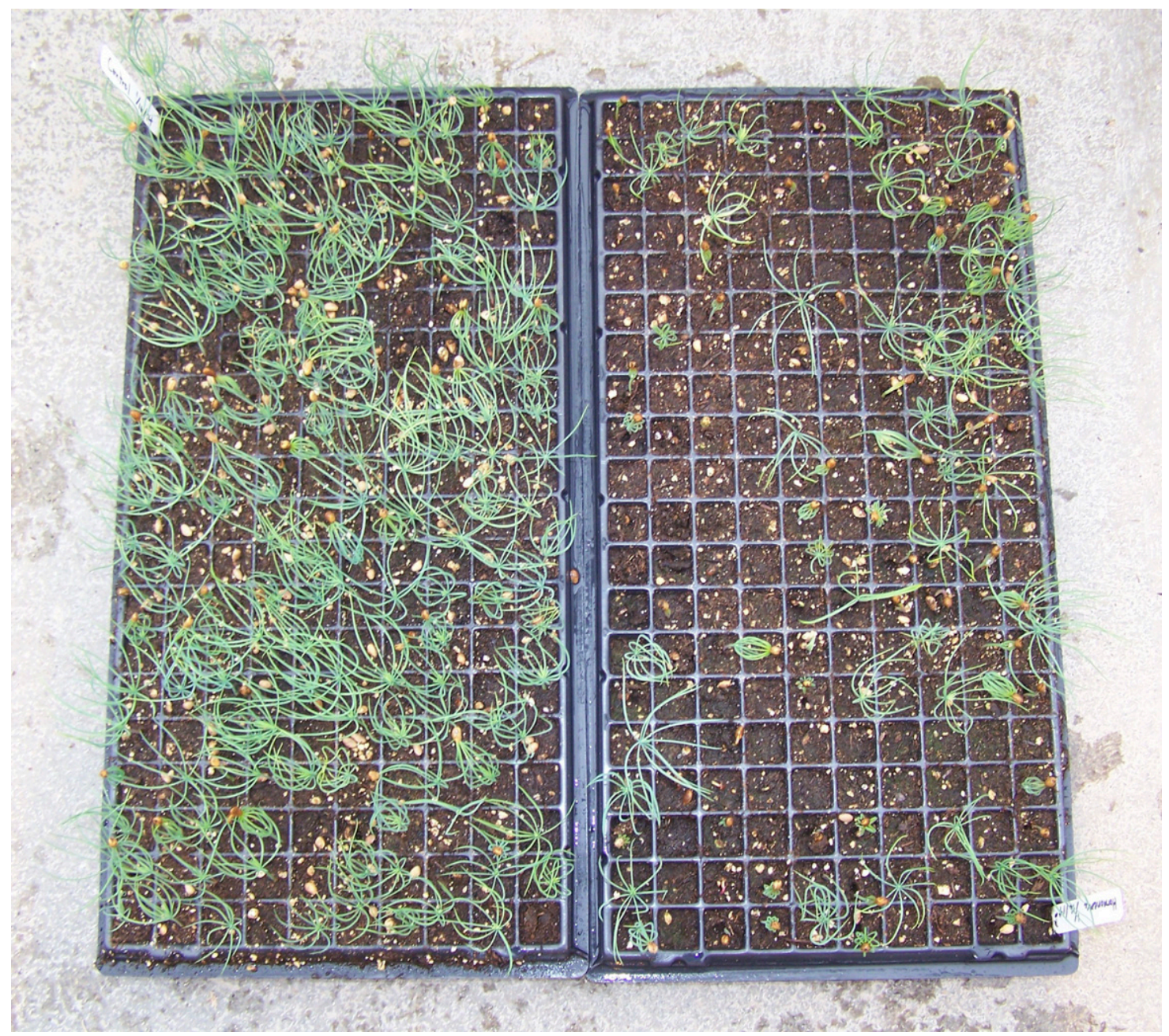

Fig. 1. Sydowia polyspora visibly reduced emergence of Pinus ponderosa germinated in seedling trays in the greenhouse, even 4 weeks after sowing. On the left, seedlings from uninoculated seed emerged rapidly and consistently; seedlings from inoculated seed (right) emerged more slowly and poorly. 
1985). Thus, its reported role here as a seed pathogen is a novel addition to the literature (Hansen and Lewis 1997). Although $S$. polyspora has been found in conifer seed in North America (Ganley and Newcombe 2006), its occurrence in seed is less common than in foliage or litter (Carroll and Carroll 1978; Ganley et al. 2004; Koukol 2009; Smerlis 1970). How the fungus might affect germination as a seed endophyte is unknown; it is possible, given our results, that it would have a negative effect.

Regardless of whether $S$. polyspora is found in the seed, we should note that seeds dispersed from the parent plant are likely to come into intimate contact with $S$. polyspora in needle litter. The potential of the fungus to function as a preemergent seed pathogen in litter layers would require further study but would be difficult to establish in situ. In our study, seeds were likely exposed to a much more concentrated inoculum than they would encounter in nature, even in endophyteenriched pine litter layers. Because we did not vary the concentration in the three experiments, we did not determine whether concentration was a key factor in reducing seed emergence. However, it is important to remember that seeds of $P$. menziesii were resistant to the concentrated inoculum employed in this study, because they germinated and emerged normally.

It is also important to note that, as a preemergent pathogen, S. polyspora does not kill the seed of Pinus ponderosa outright. Instead, it appears to slow or inhibit timely germination. Arguably, one of the most vulnerable life stages of a plant is the phase from seed to seedling. Once physiological and chemical cascades have committed the seed to germination, the seed must germinate or die (Fenner and Thompson 2005). In seeds such as $P$. ponderosa that are shortlived in soil, delayed germination might be lethal; stronger pathogens or predation might come into play (Pratt et al. 1984; Shearer and Schmidt 1970). Moreover, at the xeric end of the range of $P$. ponderosa,

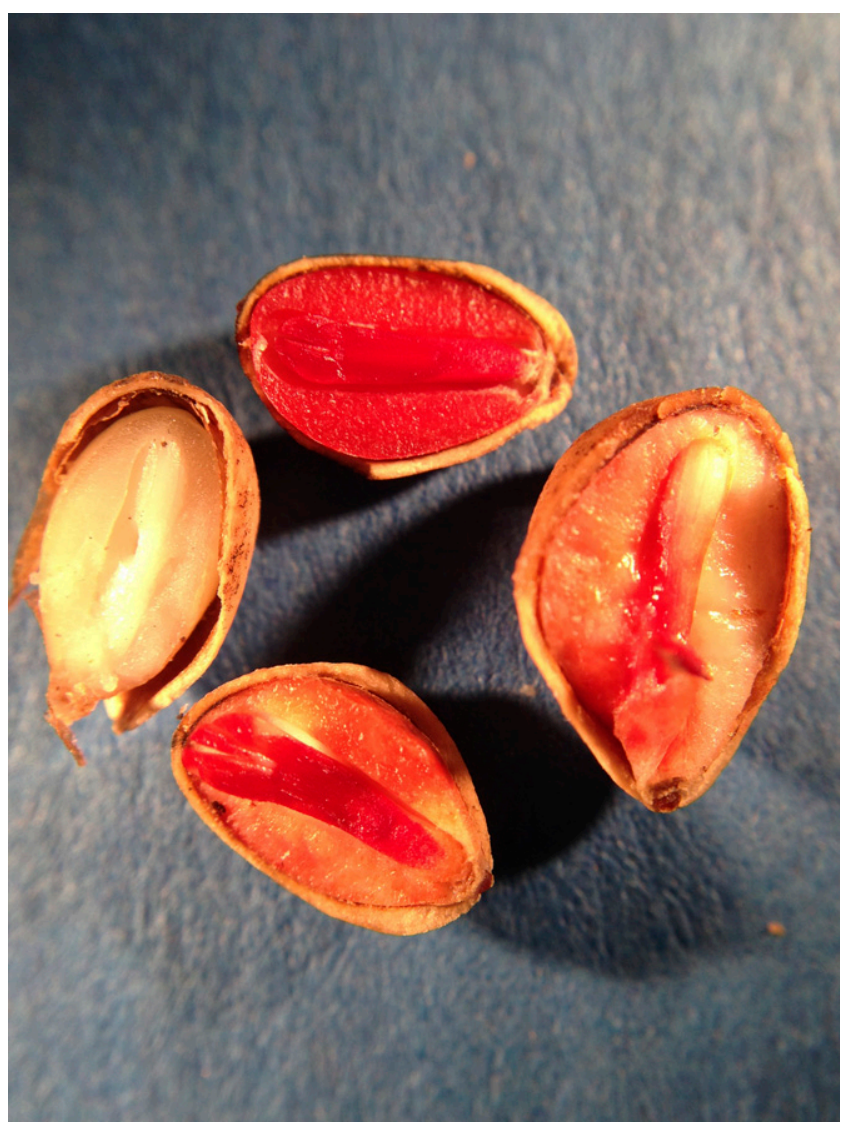

Fig. 2. Seed halves were stained with tetrazolium chloride to detect dehydrogenase in viable embryos of nonemergent seeds 4 weeks after sowing. Embryos stained red were determined to be viable or capable of germination under favorable conditions. Clockwise from left is the boiled negative control, unstratified positive control, Sydowia-inoculated seed, and the uninoculated seed. delayed germination reduces competition for valuable reserves of moisture. Thus, there may be serious fitness implications to our finding that S. polyspora can function as a preemergent pathogen.

It is also noteworthy that Lophodermium and Elytroderma spp. are at least as common in the foliar microbiome of $P$. ponderosa as $S$. polyspora (unpublished data) and are also foliar pathogens (Funk 1985). As such, they too might be expected to exert comparable if not stronger effects if they too were tested as preemergent pathogens. Among the many other microbes common to the microbiome of $P$. ponderosa, there may be a number of microbes with even stronger effects on germination and emergence of their host.

Although our findings revealed only negative effects on germination and emergence, positive effects may also be expected from endophytes. Bloomberg (1966) found that seed of Pseudotsuga menziesii endophytically colonized by Trichoderma viride had higher germination rates whereas seed colonized by Rhizopus spp. had reduced germination. Moreover, more recent research has demonstrated that soilborne fungi may have variable effects on emergence, increasing emergence in one species while decreasing emergence in a second species (Sarmiento et al. 2017). Such differential effects, some negative and some positive, have also been reported in plant-soil feedback (Klironomos 2002). In fact, endophyte-mediated, differential emergence could contribute to positive and negative plant-soil feedback that has previously been attributed to mycorrhizae or pathogens, respectively, but that has never included endophytes.

Additional broad implications may be seen in succession, because changes in plant communities must be driven by natural regeneration. An important role in seedling recruitment adds to the functional repertoire of foliar endophytes in ecosystem function and health Climate change, too, might be studied to see if it affects natural regeneration and seedling recruitment via its effects on endophytes. In sum, the ecological importance of foliar endophytes is increased by the realization that they can be either positive or negative, and that they can be involved in cryptic ways in plant community processes.

\section{Acknowledgments}

We thank those who contributed to the success of this study, particularly P. Busby, who sequenced Sydowia polyspora. Seed of Pseudotsuga menziesi var. glauca was contributed by Potlatch Corporation, with the assistance of A. Acuff.

\section{Literature Cited}

Augspurger, C. K., and Wilkinson, H. T. 2007. Host specificity of pathogenic Pythium species: Implications for tree species diversity. Biotropica 39:702-708.

Bloomberg, W. J. 1966. The occurrence of endophytic fungi in Douglas-fir seedlings and seed. Can. J. Bot. 44:413-420.

Boberg, J. B., Ihrmark, K., and Lindahl, B. D. 2011. Decomposing capacity of fungi commonly detected in Pinus sylvestris needle litter. Fungal Ecol. 4: 110-114.

Borer, E. T., Hosseini, P. R., Seabloom, E. W., and Dobson, A. P. 2007. Pathogeninduced reversal of native dominance in a grassland community. Proc. Natl. Acad. Sci. USA 104:5473-5478.

Bourret, T. B., Grove, G. G., Vandemark, G. J., Henick-Kling, T., and Glawe, D. A. 2013. Diversity and molecular determination of wild yeasts in a central Washington State vineyard. N. Am. Fungi 8:1-32.

Carroll, G. C., and Carroll, F. E. 1978. Studies on the incidence of coniferous needle endophytes in the Pacific Northwest. Can. J. Bot. 56:3034-3043.

Clay, K. 1987. Effects of fungal endophytes on the seed and seedling biology of Lolium perenne and Festuca arundinacea. Oecologia 73:358-362.

Connolly, B. M., and Orrock, J. L. 2015. Climatic variation and seed persistence: Freeze-thaw cycles lower survival via the joint action of abiotic stress and fungal pathogens. Oecologia 179:609-616.

Crist, T. O., and Friese, C. F. 1993. The impact of fungi on soil seeds: Implications for plants and granivores in semiarid shrub-steppe. Ecology 74:2231-2239.

Dalling, J. W., Davis, A. S., Schutte, B. J., and Arnold, E. A. 2011. Seed survival in soil: Interacting effects of predation, dormancy and the soil microbial community. J. Ecol. 99:89-95.

Eriksson, O., and Ehrlén, J. 2008. Seedling recruitment and population ecology Pages 239-254 in: Seedling Ecology and Evolution. M. A. Leck, V. T. Parker, and R. L. Simpson, eds. Cambridge University Press, New York.

Fenner, M., and Thompson, K. 2005. The Ecology of Seeds. Cambridge University Press, Cambridge, United Kingdom. doi:10.1017/CBO9780511614101

Funk, A. 1985. Foliar Fungi of Western Trees, No. BC-X-265. Agriculture Canada, Ministry of State for Forestry, Pacific Forest Research Centre, Victoria, BC, Canada. 
Gallery, R. E., Dalling, J. W., and Arnold, A. E. 2007. Diversity, host affinity, and distribution of seed-infecting fungi: A case study with Cecropia. Ecology 88:582-588.

Ganley, R. J., Brunsfeld, S. J., and Newcombe, G. 2004. A community of unknown, endophytic fungi in western white pine. Proc. Natl. Acad. Sci. USA 101:10107-10112.

Ganley, R. J., and Newcombe, G. 2006. Fungal endophytes in seeds and needles of Pinus monticola. Mycol. Res. 110:318-327.

Grano, C. X. 1958. Tetrazolium chloride to test loblolly pine seed viability. For. Sci. 4:50-53.

Hansen, E. M., and Lewis, K. J. eds., 1997. Compendium of Conifer Diseases. APS Press, St. Paul, MN.

Hersh, M. H., Vilgalys, R., and Clark, J. S. 2012. Evaluating the impacts of multiple generalist fungal pathogens on temperate tree seedling survival. Ecology 93:511-520.

Hoff, J. A., Klopfenstein, N. B., McDonald, G. I., Tonn, J. R., Kim, M. S., Zambino, P. J., Hessburg, P. F., Rogers, J. D., Peever, T. L., and Carris, L. M. 2004. Fungal endophytes in woody roots of Douglas-fir (Pseudotsuga menziesii) and ponderosa pine (Pinus ponderosa). For. Pathol. 34:255-271.

Huang, J., and Kuhlman, E. G. 1990. Fungi associated with damping-off of slash pine seedlings in Georgia. Plant Dis. 74:27-30.

Klironomos, J. N. 2002. Feedback with soil biota contributes to plant rarity and invasiveness in communities. Nature 417:67-70.

Knapp, A., and Anderson, J. 1980. Effect of heat on germination of seeds from serotinous lodgepole pine cones. Am. Midl. Nat. 104:370-372.

Koukol, O. 2009. Geographical distribution of Scleroconidioma sphagnicola in coniferous forests in Europe and Canada. Czech Mycol. 61:112-124.

McDonald, J. H. 2014. Chi-square test of independence. Pages 59-67 in: Handbook of Biological Statistics. Sparky House Publishing, Baltimore, MD

Meyer, S. E., Beckstead, J., Allen, P. S., and Smith, D. C. 2008. A seed bank pathogen causes seedborne disease: Pyrenophora semeniperda on undispersed grass seeds in western North America. Can. J. Plant Pathol. 30:525-533.

Moles, A. T., and Westoby, M. 2004. What do seedlings die from and what are the implications for evolution of seed size? Oikos 106:193-199.
Packer, A., and Clay, K. 2000. Soil pathogens and spatial patterns of seedling mortality in a temperate tree. Nature 404:278-281.

Pratt, D. W., Black, R. A., and Zamora, B. A. 1984. Buried viable seed in a ponderosa pine community. Can. J. Bot. 62:44-52.

Puente, M. E., Li, C. Y., and Bashan, Y. 2009. Endophytic bacteria in cacti seeds can improve the development of cactus seedlings. Environ. Exp. Bot. 66:402-408.

Raghavendra, A. K. H., Newcombe, G., Shipunov, A., Baynes, M., and Tank, D. 2013. Exclusionary interactions among diverse fungi infecting developing seeds of Centaurea stoebe. FEMS Microbiol. Ecol. 84:143-153.

Ridout, M., and Newcombe, G. 2015. The frequency of modification of Dothistroma pine needle blight severity by fungi within the native range. For. Ecol. Manage. 337:153-160.

Salerno, M. I., and Lori, G. A. 2007. Association of seed-borne Fusarium species on Pinus ponderosa with germination and seedling viability in Argentina. For. Pathol. 37:263-271.

Sanger, F., Nicklen, S., and Coulson, A. R. 1977. DNA sequencing with chainterminating inhibitors. Proc. Natl. Acad. Sci. USA 74:5463-5467.

Sarmiento, C., Zalamea, P.-C., Dalling, J. W., Davis, A. S., Stump, S. M., U'Ren, J. M., and Arnold, A. E. 2017. Soilborne fungi have host affinity and hostspecific effects on seed germination and survival in a lowland tropical forest. Proc. Natl. Acad. Sci. USA 114:11458-11463.

Shearer, R. C., and Schmidt, W. C. 1970. Natural regeneration in ponderosa pine forests in western Montana. Research Papers INT-86. Intermountain Forest Range Experiment Station, Ogden, UT.

Smerlis, E. 1970. Notes on Sydowia polyspora. Can. J. Bot. 48:1613-1615.

Talgø, V., Chastagner, G., Thomsen, I. M., Cech, T., Riley, K., Lange, K., Klemsdal, S. S., and Stensvand, A. 2010. Sydowia polyspora associated with current season needle necrosis (CSNN) on true fir (Abies spp.). Fungal Biol. 114:545-554.

Wijayawardene, N. N., Crous, P. W., Kirk, P. M., Hawksworth, D. L., Boonmee, S., Braun, U., Dai, D. Q., D'Souza, M. J., Diederich, P., Dissanayake, A, and Doilom, M. 2014. Naming and outline of Dothideomycetes-2014 including proposals for the protection or suppression of generic names. Fungal Divers. 69:1-55. 